\title{
Review of Distance Learning Solutions Used during the COVID-19 Crisis
}

\author{
Sergey V. Shaytura, ${ }^{1,2, *}$, Alina M. Minitaeva ${ }^{2,3}$, Konstantin V. Ordov ${ }^{4}$, Slaveyko G. \\ Gospodinov $^{5}$ and Vitaliy O. Chulkov ${ }^{6}$
}

\author{
${ }^{1}$ Russian University of Transport (MIIT), Moscow 127994, Moscow, Russian Federation \\ ${ }^{2}$ Russian University of Tourism and Service, Moscow 141221 Moscow, Russian Federation \\ ${ }^{3}$ Bauman Moscow State Technical University, Moscow 105005, Moscow, Russian Federation \\ Financial University under the Government of the Russian Federation, Moscow 117997, Moscow, Russian Federation \\ ${ }^{5}$ University of Architecture, Civil Engineering and Geodesy, Sofia 1046, Sofia Bulgaria \\ ${ }^{6}$ Moscow State University Of Civil Engineering (National Research University), Moscow, 129337, Moscow, Russian \\ Federation \\ *Corresponding author. Email: swshaytura@gmail.com
}

\begin{abstract}
Forced to go into self-isolation due to the coronavirus outbreak, all students had to be moved to distance learning. Imposed by the Government in a short time, distance learning has hit both the learning process and the teachers hard. This paper provides a follow up on the emergency transition to distance learning and a review of the distance learning toolkit used during self-isolation, including e-learning means and solutions: email, student portals, distance learning software, conference platforms, and virtual classrooms. It examines the benefits and shortcomings of distance education, assesses the overall efficiency of remote learning, analyzes the learning content delivered on the e-learning platforms. The conclusion has been made that distance learning, if used reasonably, can be more efficient and beneficial in certain learning areas.

Keywords: Higher Education, Form of Study, Distance Learning, Educational Software and Hardware,
\end{abstract}

Learning Content, Pandemics, COVID-19

\section{INTRODUCTION}

Due to the recent outbreak of COVID-19, many educational institutions had to shift to distance and online learning [1, 2, 3, 4]. Most Russian universities had already been offering distance (off-campus) learning options for correspondence and advanced training programs $[5,6,7]$. There were also plans for intramural studies to be partially shifted online for students' self-study and midpoint assessment $[8,9,10]$.

Even though the transition to distance and online learning was a forced measure, it was necessary.

There were also different approaches to understanding the concept of distance learning, which led to enacting the amended Federal Law No. 273-Ф3 of 24 April 2020 on Education in the Russian Federation.

It was natural for university administrators to resort to the available digital teaching toolkit. However, it quickly became clear that student portals were not designed for distance learning but only as an addition to the learning process.

Next, they resorted to distance learning software. But it turned out that additional content needed to be created and configured. Therefore, such software could not be used on the spot.
The next step was the selection of conference platforms and virtual classrooms to deliver lectures and webinars. When chosen, these platforms needed to be filled with specific content. For practical classes, special software was required, which had already been purchased and installed in university laboratories. Online replacements needed to be found urgently.

\section{RESEARCH METHODOLOGY}

This paper examines the distance learning approaches adopted by various educational institutions [11, 12, 13, 14]. There is an extensive discussion in the scientific community on digital technologies in education, their successful implementation in higher education processes, quality of distance learning $[15,16,17,18]$. As digital technologies continue to evolve, there is a definite trend for the digitalization of education. One of the main benefits of integrating digital technologies into the educational process is that the teacher has means to track the effectiveness of the learning process, student's achievements, time spent to solve a problem, comprehension, etc., while conventional controls provide for a "rough" measure of performance (e.g., final grades). Digital technology helps teachers reduce paperwork by 
replacing notebooks and reports with laptops and tablets with all information they need. Unless chosen otherwise by the instructor, homework assignments are checked and graded automatically.

There are obvious benefits for students as well. Today's digital technologies enable students to work in groups on any task or project, exchange their thoughts and ideas with the classmates and the instructor, build their own learning path, and achieve better results in a shorter time.

Devices, such as interactive tablets for presentations, seminars, and conferences, facilitate information sharing, just as 3D modeling technology provides means to graphically visualize any idea in a $2 \mathrm{D}$ plane, helping solve problems more creatively and informally [19, 20, 21].

According to some scholars, digital learning will very soon eliminate the need to write lectures down. Each student will receive the necessary learning materials and process them in real-time, working interactively. All texts will be available online and will be stored in a "cloud", virtually eliminating the negative consequences of missing a class. Also, students will be able to watch recorded lectures online at a convenient time.

Students and teachers were interviewed to assess the convenience of teaching, the availability of educational resources, and the level of achievement in distance learning.

\section{THE DISTANCE LEARNING SOFTWARE AND WEBSITES}

\subsection{Overview of distance learning software}

First, educational institutions resorted to their own websites and e-mails as tools for distance learning. The first ones went down almost immediately, unable to handle a sudden uptick in the website traffic. University administrators asked students to visit the websites at different hours.

\subsubsection{E-mail}

E-mail provides more reliable communication between teachers and students, but it has its drawbacks. First, it is not structured and, due to the overflow, e-mails do not always reach the addressee. Second, an e-mail can take a long time to be delivered. Third, an e-mail may mistakenly go to spam or another auxiliary category. It should be noted that during the pandemic, the amount of spam increased dramatically. Teachers received about 100 emails a day, all of which had to be sorted out carefully not to delete anything important. It also took some time for teachers to understand who sent the letter, find the previous correspondence, and, only then, write back.

\subsubsection{Conference calls}

This mode of communication turned out to be the most popular. In the first days of self-isolation, approximately 100 calls were received during a day, most of which were misdialed or uninformative.

\subsubsection{Student portals}

Almost all universities in Russia have a digital environment to schedule classes and monitor students' knowledge. Student portals are designed to inform students and teachers about scheduled classes, classes already held, and student progress. Unfortunately, not all students and teachers properly understand the importance of this tool and know how to use it. Student portals are not designed for interaction and go down easily if accessed by many users at a time.

\subsubsection{Distance learning platforms}

Like many other Russian universities, the Russian State University of Tourism and Services Studies uses Moodle to deliver distance learning (Fig. 1) [11, 22, 23].

Using a distance learning platform, students can access learning materials whenever they need them, pose questions either directly to the teacher or on the forum, see the news, and take midterm tests.

Moodle is a sort of a do-it-yourself educational kit. A teacher or course instructor fills in the course page, by developing, publishing, and arranging learning materials as he/she chooses, by adding links to any official documents or other web pages. This platform provides for private communication between a teacher and students, a discussion forum, and a notification service to address all course students.

\subsubsection{Virtual classroom platforms}

Zoom is the ultimate leader among virtual classroom platforms. It provides a real-time view of all attendees' faces to make sure that the students participate in the webinar and not otherwise engaged behind a screensaver. There are several layout options to display the teacher and the participants (Fig. 2, 3). Zoom also provides for sharing video clips.

This platform has its advantages. First of all, it can be used for free. A moderator may mute and unmute participants during classes, which is especially convenient for group sessions. There is a screen sharing option and a "raise hand" button.

Zoom was the first platform to be widely used by high and secondary schools in Russia, as well as for holding meetings in scientific and industrial entities. Due to the widespread use throughout the country, the servers could not handle the load and went down from time to time. 
Therefore, it is preferable to use different distance learning platforms, including paid ones.
As for other free virtual classroom platforms, the longused Skype should be mentioned. Search engines also offer video conferencing solutions (Fig. 4) [22, 23, 24].
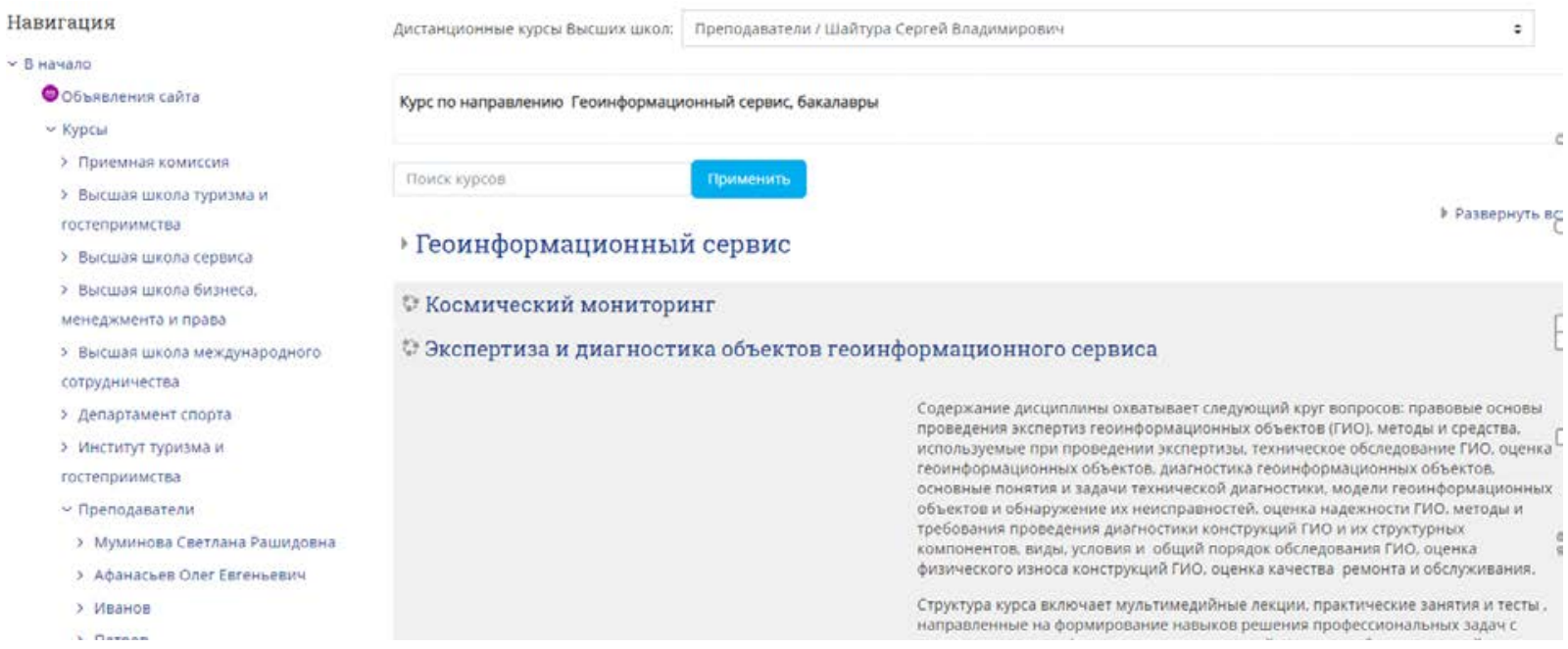

Figure 1. List of distance courses delivered through Moodle

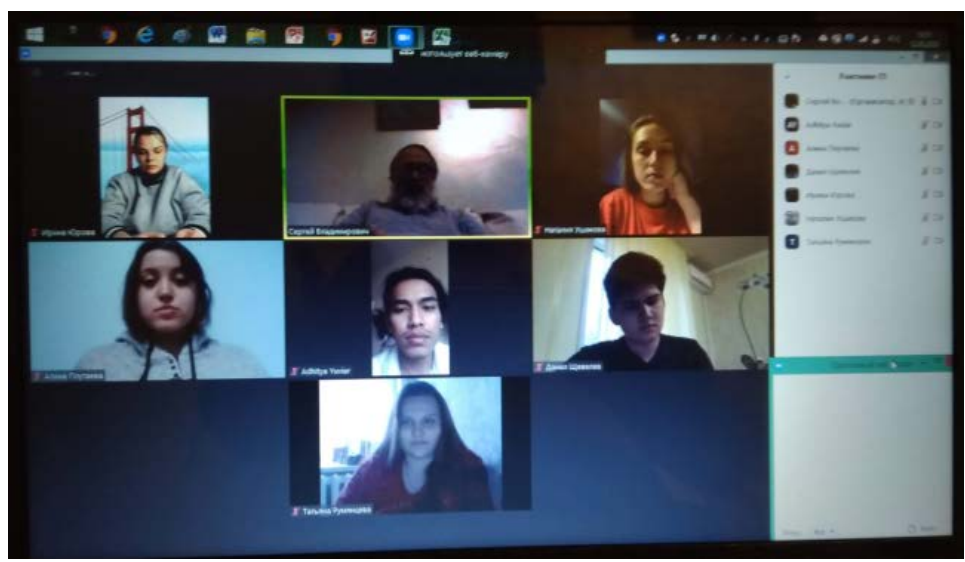

Figure 2. Zoom session

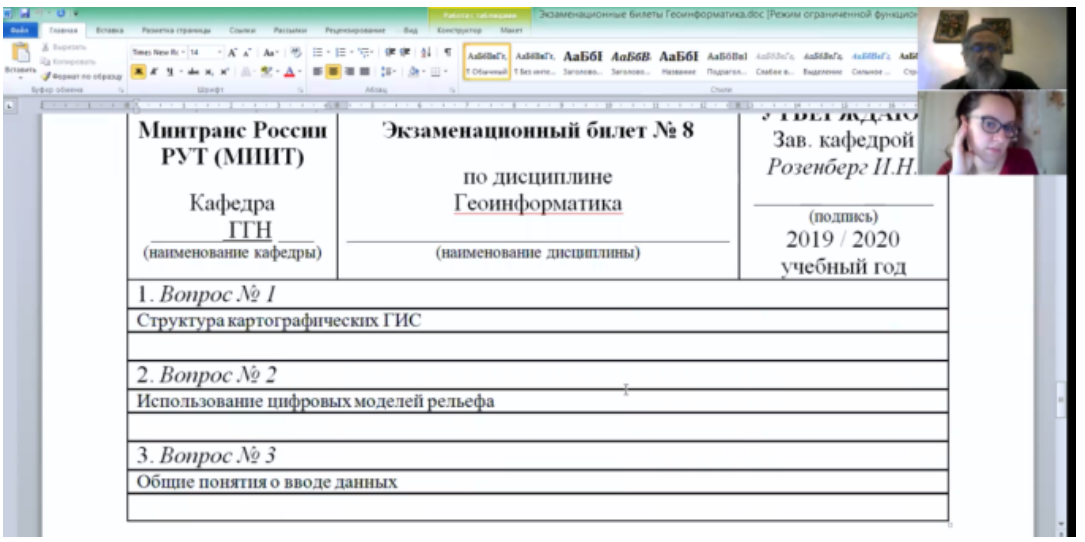

Figure 3. Using Zoom for proctoring exams 


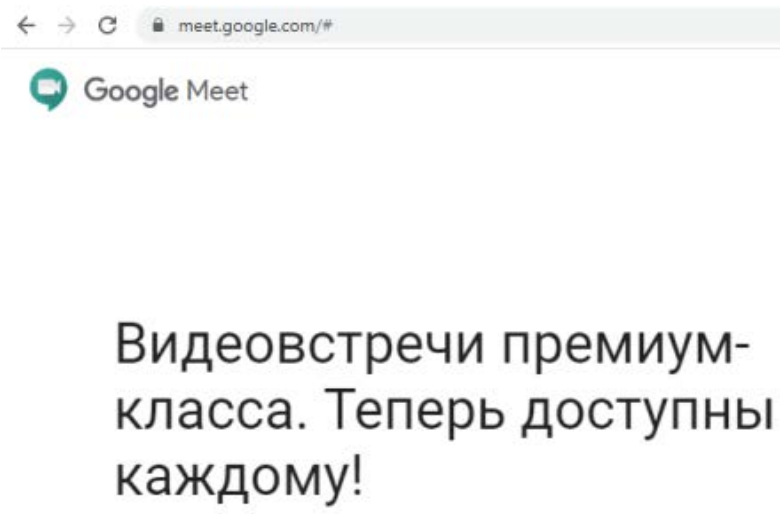

Изначально этот продукт создавался как сервис защищенных видеоконференций для бизнеса. Теперь мы сделали его бесплатным и доступным для всех.

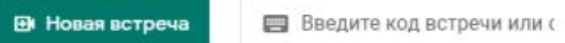

Figure 4. Google Meet for real-time meetings

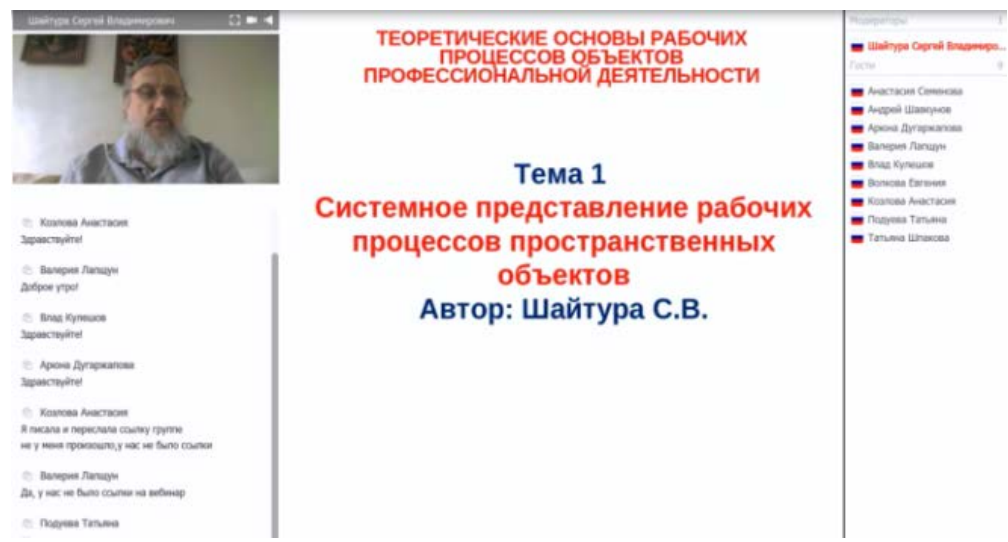

Figure 5. Delivering a lecture through Myownconference.

\subsubsection{Conference platforms to deliver lectures}

Online lectures are usually delivered through special video conference platforms, such as Myownconference (Fig. 5). This platform provides such features as screen sharing, showing slides and video clips, creating online tests and questionnaires, recording lectures. Attendees can watch webinars from their PCs or handheld devices. It is a convenient solution, but it has its own specifics. The lecturer must speak slowly, otherwise, it is difficult to understand what he or she is saying. The lecture should be recorded in a quiet room because background noises can be very annoying. All materials for the lecture should be arranged and converted into PowerPoint slides or video clips. The lecturer should also think about a proper backdrop not to distract the participants and keep them focused on the lecture. Myownconference is available free with limited functionality.
Microsoft 365 is a line of subscription services that can be used for distance learning. By purchasing a subscription license, universities provide their teachers and students with free Microsoft 365 plans offering access to Microsoft Teams communication platform, Exchange Online mailbox (50 Gb), OneDrive cloud (1 ТБ), online-based Word, Excel, PowerPoint, OneNote applications and other services. To enter, a user should sign in on office.com. Students and teachers can install classic versions of the above apps for their educational and research activities. After graduation, students will retain their address in the university ecosystem and transit to Exchange Online for Alumni.

\subsection{Educational content}

Educational content should be accessible, relevant, illustrative and stimulate learning and self-assessment. 
To assess the quality of educational content, expert opinions and compliance ratings should be consulted.

Teaching involves teaching methods and techniques used in the learning process (business games, case studies, tests, workshops, group projects and other forms of interactive and active work of students), and the teacher's competence and qualifications, namely in distance teaching [25, 26, 27]. Teaching quality assessment is closely related to quality assessment of educational content and is carried out by monitoring students' progress, achievements, and the time spent to complete the course and specific assignments [28, 29, 30].

Information technology provides for a diverse presentation of educational content and for mobile learning opportunities. A distance course can include video lectures, audio lectures, electronic textbooks, various computer animation and modeling tools to virtually perform practical assignments [31, 32, 33].

Extensive internet use and anytime, anywhere access to information resources (using smartphones, laptops) result in brand new opportunities and new requirements for distance learning and its quality assurance [34, 35].

Also, the main trends in information technology, i. e. enterprise social networking, transition to secure remote work, development of visualization software and applications, impose new requirements for employees' computer skills. Speaking about the quality of education, attention should be paid not only to higher and secondary education, but also to retraining, advanced training, and corporate training programs.

A sample survey conducted at the Russian State University of Tourism and Services Studies and the Russian University of Transport showed that about 80 percent of all students use search engines to find literature for selfstudy, and 40 percent use YouTube videos for self-study.

\subsection{Overview of e-learning websites}

International distance education is experiencing rapid growth. Education is a top priority for any country. The United Kingdom is the leader in remote learning, immediately followed by the United States. The leading educational institutions in the United Kingdom and the United States also offer free online courses [13]. Unfortunately, to attend such courses, students must be fluent in English.

Below is a summary of the most popular e-learning websites.

1. UMass Boston OpenCourseWare (http://ocw.umb.edu/) offers courses in Psychology, History, Biology, Mathematics, Political Science, Humanities. Biology and Mathematics can be useful for specialty schools delivering English-taught programs. As for History, Political Science, Psychology, and Humanities, they are naturally taught from the pro-American point of view as the main goal of education is to foster the values beneficial for the program sponsors.

2. Khan Academy (http://www.khanacademy.org/) provides many teaching videos and almost no texts.
3. Coursera (https://www.coursera.org/) is a large database containing free online courses created by many universities. There is also a Russian version for courses in Russian. This website would be useful for those who choose self-education. Founded by Stanford University, this platform brings together 33 universities from different countries. The leading Russian universities, Higher School of Economics and Moscow Institute of Physics and Technology, have prepared several online courses for Coursera. Unfortunately, Coursera fees are higher than full-time tuition fees in Russian universities.

4. Connections

Academy (http://www.connectionsacademy.com/home.aspx) is a website in English offering tuition-free courses for children of all ages. It can be useful for specialty schools delivering English-taught programs.

5. New York University (https://files.nyu.edu/jmg336/public/html/mathematics.htm l) offers Mathematics courses in downloadable PDF format.

6. Open Yale Courses (http://oyc.yale.edu/) provides free access to a selection of courses taught by distinguished teachers and scholars at Yale University. All lectures are available online and can be downloaded. Registration is required.

7. University of the People (http://www.uopeople.org/groups/tuition-free-online-

degree) is a private resource offering several Bachelor and Master degree programs, including those in business administration and computer technology.

8. E-Learning Center (http://www.elearningcenter.com/free.htm) offers courses in computer science and information technology taught in English. Registration is required.

9. National Open University INTUIT (http://www.intuit.ru/intuituser/userpage) offers free courses taught in Russian, including retraining and advanced training programs. A Certificate of Completion will be issued free of charge. For a nationally recognized certification, a fee is charged.

The above overview of e-learning websites shows that the main subjects that are taught remotely are History, Political Science, Cultural Studies, Mathematics, Physics, Management, Economics, Computer Science, and Information Technology.

Both paid and free courses are available. The free ones are usually either introductory or promotional. Considering the great attention paid to remote learning in the UK and the US, Russia is trying to keep up. In addition to the above websites, almost every university offers correspondence and distance courses, with some of the classes conducted extramurally, and some - intramurally.

One of the global trends in education is the speedy development of open online education. The global university community is well on the way to uniting and developing free educational resources.

The development of distance learning has its challenges, namely: administration of online resources, quality assessment of remote education, distance learning as an integral part of the independent work of full-time students. 


\section{THE ADVANTAGES AND DISADVANTAGES OF DISTANCE LEARNING}

\subsection{Drawbacks of distance learning}

Distance learning has its shortcomings:

A great amount of effort is required to develop an online course.

Facing the requirement to master almost all learning materials independently, online students need to have strong motivation and a lot of willpower, responsibility, and self-control to succeed.

There is no direct communication between the student and the teacher. The emotional component promotes the learning process and facilitates information processing, and teamwork boosts creativity.

There are certain technical requirements for online courses. Therefore, to study remotely, a student needs a good computer and Internet access, but, unfortunately, not everyone can afford it.

There is poor development of communication skills. In remote learning, a student has minimal contact with fellow students and teachers. This form of training is not suitable for the development of communication, teamwork skills, and confidence.

There is a lack of practical training. In full-time education, students can participate in business games, perform laboratory research with a teacher, which is difficult to implement in remote learning.

Special teacher training is required. In remote learning, a teacher must be able to determine the student's mood and individual features remotely. This requires a teacher to have rather complex knowledge and skills, special and sufficient training.

\subsection{Benefits of distance learning}

In remote learning, a student can study anytime and anywhere, at a pace convenient for the student, depending on his or her capabilities [16, 17, 18, 19, 20].

Another benefit is the availability of education for anyone, regardless of personal circumstances. Remote learning also ensures social equality - equal education opportunities for anyone, regardless of the student's place of residence, health, and financial situation.

Remote learning has a positive effect on students, increasing their creative and intellectual potential through self-organization, drive for knowledge, development of computer skills, and independent decision making.

Another benefit is the development of high-quality educational programs. Well-designed training programs and courses take distance education to a whole new level. Now, new courses, interactive lectures are being developed, and speedy Internet connection allows for even more interactive communication and discussion on forums. Creative freedom is another advantage of distance learning: comfortable conditions are provided for the students' creative self-expression, they can perform assignments in their own unique manner, different from the others, without cheating. Another great benefit is the reduction in the cost of education both for the organization delivering it and for the student. Thus, distance learning contributes to the development of students' cognitive skills, critical and creative thinking, the ability to independently structure their knowledge, navigate the information space, foster a sense of responsibility for the results of their own educational and cognitive activities, and allows to improve the quality of education and optimize costs. The main advantages of distance education are convenience, mobility, and individual approach.

Technological efficiency: state-of-the-art software and hardware contribute to increasing the efficiency of elearning;

Accessibility and openness of education: distance learning provides education opportunities for students around the world, through a computer and Internet access;

Customized education: distance learning is more flexible. A student can determine the pace of learning, returning to topics and sections for more in-depth study, the intensity, and duration of classes;

The nature of instruction materials: instruction materials should be developed to take into account the significant proportion of students with little or no distance learning experience;

Using a smartphone or tablet, with which no modern person ever parts, remote students can learn anytime, on their own schedule, while staying in the "comfort zone" and maintaining their familiar environment and lifestyle.

Distance learning is much more cost-effective than the conventional one both for students (they only pay the access and assessment fees) and for university administrators (there is a significant reduction in the teaching staff and premises maintenance costs after the programs and courses are developed).

\section{DISCUSSION OF RESULTS}

In recent years, interest in e-learning has increased so much that conventional educational institutions have begun to include online courses in their educational programs as a mandatory component $[17,18,19,20,21]$.

E-learning is becoming increasingly relevant after the new-generation federal educational standards were adopted, resulting in a reduction in the number of classroom activities and expansion of students' independent activities. On the one hand, e-learning opens new educational opportunities, however, on the other hand, the standards impose rather stringent requirements on the electronic educational environment of educational organizations.

It should also be noted that the expansion of online learning in the country requires quite serious methodological support in terms of creation technologies and implementation conditions. 
Thus, distance learning is a promising form of training that allows people to obtain qualifications in the educational institutions they like, regardless of many factors that limit the ability to study full-time. Distance education has many advantages and benefits. However, at the present stage of development, many challenges arise due to the lack of the necessary hardware in Russia. Of course, the development of computers and digital technologies provides many additional opportunities in the educational process. But it should be noted that no technology can replace a living person and convey the emotional component provided by a teacher, and, therefore, distance learning should not massively replace conventional education. In the future, everyone will become familiar with distance learning, which will be considered not only as a means of upgrading qualifications but also as a means of obtaining both advanced and primary vocational education [2].

The development of distance learning depends on many factors and the transformation of the thinking and perception of both students, teachers, and employers. In such conditions, students must be open to new things, teachers must continuously improve their qualifications, and employers must be willing to hire staff trained online.

\section{CONCLUSION}

The sudden and compulsory transition to and unpreparedness for distance learning caused a sharp antipathy to distance education among teachers and students, which resulted in a huge amount of ridicule and mockery of teachers on social media. It is a pity. Firstly, teachers are not the ones to blame for being thrown in combat without being given the armory. Secondly, distance learning is a more effective teaching method, provided it is used reasonably and in the right proportion. Summing up, it should be noted that considering the growing demand for e-learning, more attention should be paid to the development of modern online courses with an emphasis on supplementary vocational education (advanced training and retraining programs, master of business administration, etc.), as the target audience of elearning is mostly interested in acquiring professional skills. E-learning allows adapting training programs to the needs of all students (those combining study and work, mastering several educational programs at a time, with disabilities, etc.) in terms of the accessibility of the educational environment, without reducing the quality of learning.

Effectively managed e-learning is an important factor in the innovative development of modern education, particularly higher education. Complementing the conventional learning process, well-balanced e-learning should be a priority for the development of the education system in the context of globalization, mass digitalization, and socialization of services and technologies. E-learning, which is increasingly seen as the $21^{\text {st }}$-century educational paradigm, is becoming one of the most effective ways to overcome the isolation of the Russian educational system.

\section{REFERENCES}

[1] Abramov A. V., Bagdasaryan V. E., Byshok S. O., Volodenkov S. V., Evstaf'ev D. G., Egorov V. G., Komleva N. A., Kramarenko N. S., Manoilo A. V., Mikhailenok O. M., Petrenko A. I., Prokof'ev V. F. Pandemia COVID-19: The end of the familiar world? In: Bulletin of Moscow Region State University (ejournal), 2020, no. 2. Available at: www.evestnikmgou.ru

[2] Bukeikhanov N., Gvozdkova S., Butrimova E. Evaluation of the effectiveness of digital teaching technologies in the conditions of COVID-19 // Russian regions: looking into the future, 2020, vol 7, N 2 pp. 62 $-75$

[3] Grishin V.I., Domashchenko D.V., Konstantinova L.V., Koshkin A.P., Ustyuzhanina E.V., Shtykhno D.A., Shubenkova E.V. Life after the Pandemic: Economic and Social Consequences. Vestnik of the Plekhanov Russian University of Economics. 2020;(3):5-18. (In Russ.) https://doi.org/10.21686/2413-2829-2020-3-5-18 Shaytura S.V. Distance education during a pandemic // Slavic forum. - 2020. - № 2 (28). - pp. 201 - 205.

[4] Dick V.V., Shaytura S.V., Urintsov A.I. Experience of international cooperation in the standardization and certification of learning content // Slavic forum. - 2015. - № 2 (8). - pp. 60 - 67.

[5] Gerasimova V.G., Sorokina M.Y. Some issues in training in e-learning environment // Slavic forum. 2016. - № 1 (11). - pp. 61 - 67.

[6] Gvozdkova S.I., Shvartsburg L.E. Experimental Studies of Steady-State Sources of Vibrations of Machinery Production Process Equipment to Substantiate Choice of Vibration Protection Methods// Lecture Notes in Mechanical Engineering. 2020. pp.141-149. Doi:10.1007/978-3-030-22063-1_16.

[7] Kudz, S. A. Soloviev, I. V. Tsvetkov, V. Ya. Spatial Knowledge Ontologies // World Applied Sciences Journal. -2014. - 31 (2). - pp. 216-221.

[8] Novomodny I.Yu., Nikiforova D.P. Organization of the work of an educational institution during distance learning // Problems of pedagogy. 2020. No. 2 (47). S. 69-71.

[9] Pashkin S.B., Lisovskaia1N. B., Pchelkin V.O., Sarkisova E.A. Digitalization as a new direction in education sphere // Educational bulletin "Consciousness” - 2020 Vol.22. № 6- pp. 21 -30 
[10] Brodovskaya E.V., Dombrovskaya A.Yu., Pyrma R.V., Azarov A.A. Criteria for Rating the Level and Quality of Digitalization of the Educational Process in Universities of the Russian Federation. Vestnik Volgogradskogo gosudarstvennogo universiteta. Seriya 4. Istoriya. Regionovedenie. Mezhdunarodnye otnosheniya [Science Journal of Volgograd State University. History. Area Studies. International Relations], 2020, vol. 25, no. 2, pp. 268-283. (in Russian). DOI: https://doi.org/10.15688/j volsu4.2020.2.20

[11] Korepanova Natalia V., Starodubova Elena A., (2020). Distance Learning: Challenges and Prospects. Cross-Cultural Studies: Education and Science, Vol.5, Issue 2(2020), pp. 139-149 (in USA) Shaytura S.V. Distance education methods in geoinformation service// Slavic forum. - 2020. - № 1 (27). - pp. 177 - 188.

[12] Shaytura S.V., Ordov K.V., Minitaeva A.M. (2019). Digital learning methods for the digital economy. Proceedings of the International Scientific and Practical Conference on Digital Economy (ISCDE 2019), Yekaterinburg, Russia, pp. 606-611 https://doi.org/10.2991/iscde-19.2019.117

[13] Bukeikhanov N.R., Gvozdkova S.I., Butrimova E.V. Automated Resource-Saving System for the Use and Regeneration of Epilam-Based Lubricating-Cooling Technological Liquid// Lecture Notes in Mechanical Engineering. 2020. - pp.1435-1442. Doi:10.1007/9783-030-22063-1_151.

[14] Savinykh G.P. Remote technology appraisal activities in the education system // Slavic forum. 2015. - № 1(7). - pp. 249 - 254.

[15] Maslova Maria Al., Lagutkina Tatiana Vl. Analysis and identification of positive and negative aspects of distance learning implementation // Research result. Information technologies - 2020 vol 5 № 2. C. 54-60.

[16] Shaitura S.V., Knyazeva M.D., Feoktistova V.M., Vintova T.A., Titov V.A., Kozhaev Yu.P. Philosophy of information fields // International Journal of Civil Engineering and Technology. 2018. T. 9. № 13. C. 127136.

[17] Shaytura S.V., Minitaeva A.M., Rosenberg I.N., Kozhaev Yu.P. 3D modeling and creation of panoramas - Monograph - Burgas, 2019.
[18] Shaytura S.V., Sumzina L.V., Rosenberg I.N., Vintova T.A. Modeling and visualization of threedimensional spatial objects - Monograph - Burgas, 2018.

[19] Minitaeva A.M., Feoktistova V.M. Geoinformation services in a spatial economy // International Journal of Civil Engineering and Technology. 2018. T. 9. № 2. C. 829-841.

[20] Alekseeva T.V. Google services for education // Slavic Forum. - 2015. - No. 2 (8) - p. 13-21. Alekseeva T.V., Dick V.V., Kokoreva L.A. Operational data analysis in electronic business // Slavic Forum - 2014. No. 2 (6) - pp. 6-12.

[21] Alekseeva T.V., Kokareva L.A. Cloud services for student collaboration // Slavic Forum - 2013. - No. 2 (4). - from. pp. 6-12.

[22] Shaitura S.V., Kozhaev Yu.P., Ordov K.V., Antonenkova A.V., Zhenova N.A. Performance evaluation of the electronic commerce systems // Espacios.- 2017.- T. 38.- № 62.- C. 11.

[23] Shaitura S.V., Minitaeva A.M, Ordov K.V., Shaparenko V.V. Virtual enterprises in a spatial economy // International Journal of Recent Technology and Engineering (IJRTE) -2019. T. 7. № 6. C. 719 - 724.

[24] Shaitura S.V., Ordov K.V., Lesnichaya I.G., Romanova Yu. D., Khachaturova S.S. Services and mechanisms of competitive intelligence on the internet // Espacios.- 2018.- T. 39.- № 45.- C. 24.

[25] Shvartsburg L.E, Yagolnitser O.V, Butrimova E.V. Development of Integrated Criterion to Select Environmentally Sound Cutting Fluids and Relevant Application Systems in Shape-Forming Processes// Lecture Notes in Mechanical Engineering. 2020. pp.281-288. Doi:10.1007/978-3-030-22063-1_31.

[27] Tsvetkov V. Ya. Information Space, Information Field, Information Environment // European researcher. 2014. № 8-1(80). pp.1416-1422. DOI: 10.13187/issn.2219-8229

[28] Tsvetkov V. Ya. Worldview Model as the Result of Education // World Applied Sciences Journal. -2014. - 31 (2). - pp.211-215

[29] Tsvetkov V.Ya. Cognitive information models. // Life Science Journal -2014. -11(4). - pp.468-471. Tsvetkov V.Ya. The K.E. Shannon and L. Floridi's Amount of information // Life Science Journal 2014;11 (11), pp.667-671 
[30] Tsvetkov V.Ya., Shaytura S.V., Ordov K.V. (2019). Digital management railway. Proceedings of the International Scientific and Practical Conference on Digital Economy (ISCDE 2019), Yekaterinburg, Russia, pp. 181- 185 https://doi.org/10.2991/iscde-19.2019.34

[31] Tsvetkov V.Ya., Shaytura S.V., Sultaeva N. L. Digital Enterprise Management in Cyberspace. Proceedings of the 2nd International Scientific and Practical Conference "Modern Management Trends and the Digital Economy: from Regional Development to Global Economic Growth” (MTDE 2020),

Yekaterinburg, Russia, pp. 361 - 365

https://doi.org/10.2991/aebmr.k.200502.059

[32] Xiaohao D., Changjun C. A Study on the Employment of Graduates of Higher Education in the Context of the Financial Crisis // Procedia - Social and Behavioral Sciences. Vol. 77, 2013, pp 164-168. 